\title{
The impacts, characterisation and management of human-leopard conflict in a multi-use land system in South Africa
}

\author{
N. L. Constant ${ }^{1,2,3}$ (D) S. Bell ${ }^{1}$ R. A. Hill ${ }^{1,2}$
}

Received: 30 March 2015/Revised: 29 July 2015/Accepted: 10 August 2015/

Published online: 29 August 2015

(C) The Author(s) 2015. This article is published with open access at Springerlink.com

\begin{abstract}
Human-carnivore conflict represents a global problem, negatively impacting carnivore populations and local livelihoods worldwide. Game farming in South Africa has increased introducing a new form of conflict due to predation on game, but is poorly understood. We contribute to this deficit by adopting an interdisciplinary research approach bringing together quantitative and qualitative data with longitudinal engagement with farmers. We assess the impacts, characteristics and management of human-leopard conflict on game and livestock in the Blouberg Mountain Range. Leopards represented $89 \%$ of reported game attacks with the highest number of attacks on impala and $60 \%$ of reported livestock attacks. The economic costs of leopard predation were highest for nyala compared to other game species and the financial cattle and donkey losses represented large economic costs for communal farmers compared to commercial farmers. Both farming communities experienced a reduced sense of wellbeing and for communal farmers, negative spiritual and cultural impacts. The spatial predation risk of game attacks were most affected by increasing distance to water and the risk of predation on livestock attacks increased further away from villages. Livestock attacks were associated with seasonal grazing patterns and the erosion of traditional management livestock strategies due to the economic costs of their implementation and the migrant labour system altering management roles in the community. The timing of game attacks by leopards was related to the birthing seasons for game and seasonal changes in water supply. Similarly, temporal
\end{abstract}

Communicated by David Hawksworth.

Electronic supplementary material The online version of this article (doi:10.1007/s10531-015-0989-2) contains supplementary material, which is available to authorized users.

N. L. Constant

n.1.constant@durham.ac.uk

Department of Anthropology, Durham University, South Road, Durham DH1 3LE, UK

2 Primate \& Predator Project, Lajuma Research Centre, P.O Box 522, Louis Trichardt, Makhado 0920, South Africa

3 Geography and Environmental Management, University of the West of England, Bristol, UK 
patterns on livestock were related to the calving season and land degradation in communal areas.

Keywords Carnivores - Leopards - Human-wildlife conflict - Risk of predation - Game predation $\cdot$ Livestock predation

\section{Introduction}

Conservation efforts in the twenty-first century face unique challenges; reconciling the requirements of human activities with the needs of wildlife in changing ecological, socioeconomic and political landscapes (Barua et al. 2013). The expansion of human presence into wildlife habitats due to human population growth and land use transformation has caused habitat loss, degradation and fragmentation for many species (Inskip and Zimmermann 2009). Conflicts involving large carnivores result from their protein-rich diets and extensive home ranges, drawing them into competition with humans (Treves and Karanth 2003). People that depend on game and livestock are at risk because wildlife damage and predation impose significant economic and hidden costs, which induce negative social and cultural impacts to affected farmers (Barua et al. 2013).

Leopards (Panthera pardus) are the most widespread felid worldwide and are able to persist in a diverse range of habitats. Nevertheless, the species has experienced a $37 \%$ reduction in its historical range throughout southern Africa over the past 100 years (Ray et al. 2005). Habitat degradation and fragmentation, depletion of natural prey species, poorly managed harvests, illegal trade of leopard skins and human-leopard conflict have contributed to the decline (Balme et al. 2010; Henschel 2008; Packer et al. 2011; Ray et al. 2005). The number of game farms in South Africa has increased from 3500 in 1992 to 10,000 in 2011 (Tibane and Vermeulen 2014). Game farming introduces a new form of emerging conflict due to depredation on expensive game (Lindsey et al. 2009). To our knowledge, published data on the impacts, characterisation and management of humancarnivore conflict on game populations are lacking worldwide (Inskip and Zimmermann 2009), with only two studies to date assessing the impacts and determinants of humancarnivore conflict on game populations in South Africa (Thorn et al. 2012, 2013). Ecological niche models have been adopted as a tool to integrate the effects of bio-physical, anthropogenic and spatial factors to develop spatial predation risk maps for livestock by pumas (Puma concolor) and jaguars (Panthera onca) in Mexico (Zarco-González et al. 2012), and large carnivores in Tanzania (Abade et al. 2014). The approach offers considerable scope to spatially predict the patterns of leopard predation on both game and livestock and to assess their role as drivers of human-wildlife conflict in South Africa.

In Limpopo Province, South Africa, leopards are killed legally and illegally because of the threats they pose to game and livestock and on very rare occasion's human life (Constant 2014). To date research on human-wildlife conflicts has focused on providing alternative solutions to managing problem animals that do not rely on retaliation alone (Treves et al. 2009). However, many strategies applied to protect livestock such as shepherds and livestock-guardian dogs produce opportunity costs for people including loss of sleep, reduced school attendance, employment opportunities and greater exposure to disease, but are rarely explored by researchers (Barua et al. 2013). Researchers advocate a need to adopt participatory approaches that draw on the experiences of local people 
affected by wildlife in order to develop locally relevant mitigation strategies, since currently, these groups are largely underrepresented (Hill 2004).

Human-wildlife conflict practitioners stress a need for interdisciplinary research on the human dimensions of conflict (Dickman 2010; Treves et al. 2009) and the need to incorporate quantitative and qualitative methods in conservation research involving humans (Drury et al. 2011). We adopt an explicitly interdisciplinary and multi-method research approach to address the impacts, characterisation and management of humanleopard conflict. We bring together quantitative and qualitative data on the impacts of depredation and factors influencing the spatial and temporal patterns of attacks, with longitudinal engagement with farmers to measure the economic, ecological and social implications of human-leopard conflict in the Blouberg Mountain Range, South Africa. Through participatory research approaches we integrate local experiences and perceptions of locally adopted mitigation strategies to inform recommendations for the management of human-leopard conflicts.

\section{Materials and methods}

\section{Study area}

The study area encompassed the Blouberg Mountain Range, an inselberg with the highest peak of $2051 \mathrm{~m}$, incorporating the Maleboch Nature Reserve, Blouberg Nature Reserve and the Lanjan Nature Reserve in the Limpopo Province, South Africa (Fig. 1). The Blouberg Mountain Range falls under the Blouberg Municipality, forming part of the
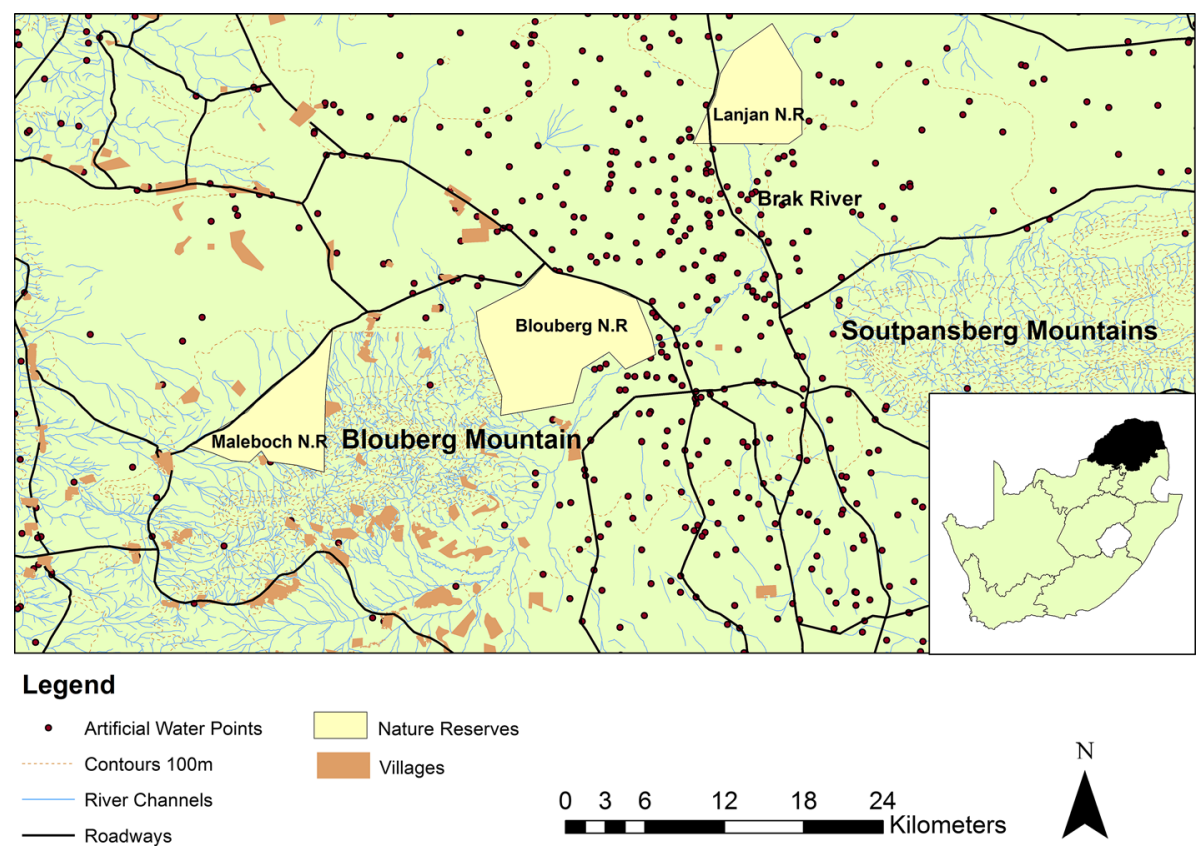

Fig. 1 Study site of the Blouberg Mountain Range in the Limpopo Province of South Africa 
Capricorn District (Blouberg Local Municipality 2013-2016). The Blouberg Municipality has 138 villages with a population of 195,000 (Blouberg Local Municipality 2013-2016).

The Blouberg Mountain and its surrounds are home to a large rural population descended from the Bahananwa and other cultural groups, including the Batlokwa, Vha-Venda and Shangaan (Blouberg Local Municipality 2010-2011). The rural villagers operate a communal land use system based on subsistence agriculture and livestock farming and hereafter are referred to as communal farmers. The Blouberg also has a large commercial agricultural sector based on crop, cattle and game farming, with Afrikaans speaking commercial farmers whose properties incorporate a range of these activities.

The Blouberg is semi-arid, with a warm and dry summer from October to March and a dry winter season from April to September (Limpopo Provincial Government 2004). The average monthly maximum temperature for the area ranges from $22{ }^{\circ} \mathrm{C}$ in July to $31{ }^{\circ} \mathrm{C}$ in February and the Blouberg is coldest during July when average monthly temperatures drop to $9{ }^{\circ} \mathrm{C}$ at night (NCC-Group 2012). Carnivores present in the area include leopard (Panthera pardus), cheetah (Acinonyx jubatus), caracal (Caracal caracal), brown hyaena (Hyaena brunnea), spotted hyaena (Crocuta crocuta), and black backed jackal (Canis mesomelas).

\section{Interdisciplinary research methods}

The majority of studies worldwide apply quantitative analyses of human-wildlife conflict patterns and rarely consider the application of qualitative methods (Michalski et al. 2006; Soto-Shoender and Giuliano 2011; Thorn et al. 2012, 2013). Qualitative studies concentrate on the data quality associated with relations between people and do not make broad claims about a population; instead they seek an in-depth understanding of individuals or subgroups and the processes influencing values and behaviours (Drury et al. 2011). Drury et al. (2011) stress the importance of qualitative research for understanding the local context, highlighting new research topics and aiding accurate interpretation and analysis. Here, we incorporate quantitative and qualitative research methods and analysis for a more holistic overview of the conflict problem.

We undertook ethnographic field observations in two farming communities in the Blouberg region. Ethnography is defined as a process where research practitioners are conducting: "participant-observation paired with a range of other methods, living within a community, and getting deeply involved into the rhythms, logics, and complications of life as lived by a people in a place, or perhaps by peoples in places" (McGranahan 2015, p. 24). This approach builds trust between researchers and the people that they research. Communal farmers were initially suspicious that we worked for wildlife authorities and were trying to uncover poachers, whilst commercial farmers were resistant to outsiders, because of high incidents of poaching. Over time, we were invited to social events and interacted with both farming communities, allowing us to learn about the local language and culture. The ethnographic approach allowed us to obtain in-depth insights about the local people that would not have been possible from single visit interviews including the cultural and emotional values associated with livestock and depredation, historical livestock management practices and social and cultural change. Longitudinal engagement with the same farmers during 18 months of fieldwork uncovered, clarified and confirmed a wide range of data to be recorded, coded, sorted and verified within an ethnographic diary.

Inspired by a cultural mapping technique developed by Strang (2010) we adopted a similar methodology to explore the economic, ecological and social implications of human-leopard conflict. Cultural mapping is an ethnographic method for gaining access to 
people's historical and contemporary relationships with the local environment by taking guided walks through the places they deem important and collecting a range of historical, social and ecological data in situ (Strang 2010). We walked with 42 commercial $(n=19)$ and communal farmers $(n=23)$ through their farming landscapes to observe and discuss their impressions using semi-structured interviews and participant observation. We adopted a purposive (targeted) sampling strategy and snowball sampling strategy to identify villages/farms where communal and commercial farmers were likely to graze their livestock in leopard habitat and informants that had experienced game or livestock losses.

Such an in situ dialogue offers several advantages for analysing human-leopard conflict. Firstly, the farmer becomes the 'bearer' of information about what it typically means to be part of the social-ecological farming landscape, which compensates for the asymmetry in the interviewing process. The local knowledge possessed by farmers in the study relates to the changing ecological and social conditions taking place in the farming landscape, knowledge of leopard presence and locally-adapted management practices to mitigate conflict. Furthermore, cultural mapping allows for the simultaneous collection of multiple data sets using different methods, which saves time and resources. The interviews were semi-structured to allow flexibility to incorporate topics deemed important by the interviewees. We took detailed notes using participant observation and longitudinal engagement allowed for the continuous validation of data using a range of visual and oral checks. Data was collected in a variety of forms from notes, recorded transcripts, photographs, GPS waypoints and maps. Interviews were conducted in Northern Sotho, through the assistance of a translator, whilst all interviews with commercial farmers took place in English. Local observations of the landscape commented on by farmers opened up new avenues for discussion and enquiry.

During the walks we drew on the local knowledge of farmers to capture and map biophysical data of the ecological setting. This included the locations of reported game and livestock attacks related to specific predators occurring from October 2009 to October 2011. Respondents were asked whether the predator was identified through either (1) a direct sighting of the predator; (2) an indirect sighting around the kill e.g. spoor of the carnivore and kills stashed in trees; or (3) signs on the carcass e.g. bite marks to the neck conditions. Informants were shown photographs of the five carnivore species and their spoor to assist in the correct identification of the predator. Game and livestock attacks were recorded as occurring in the dry (April-September) or wet season (October-March). In addition we collected information on landscape characteristics such as water points, rivers, farm boundaries and village locations recorded using a global positioning system (GPS).

\section{Data analysis}

Ethnographic data from participant observation and cultural mapping were transcribed and uploaded into NVivo 9 (QSR International 2009). Interview transcriptions and ethnographic data were coded to specific research themes such as the impacts of depredation and economic impacts of mitigation strategies. This form of analysis is defined as grounded theory, which places less emphasis on pre-defined theory; rather, the data generates ideas and then themes emerge, which allow the researcher to identify and apply relevant theoretical frameworks (Emerson et al. 2011). Grounded theory approaches towards data analysis attempt to make "frequent comparisons across the dataset, the researcher can develop, modify and extend theoretical predispositions so they fit the data" (Emerson et al. 1995, p. 143).

Quantitative survey data were evaluated using summary statistics and statistical analysis. Accurate game numbers for different species were unavailable on many commercial 
farms as well as the different forms of loss over the study period. The percentage of the total herd size for each livestock species lost to predators, stolen, disease and accidental death was compared using a Kruskal-Wallis Test (KWT). Financial evaluations of livestock and game losses were calculated based on average annual market prices in South African Rand and the age and sex of game and livestock (see Supplementary Information, Online Resource 1).

To measure the temporal predation risk of game and livestock attacks in relation to mean monthly rainfall, the absolute number of game and livestock killed each month was pooled together and totalled over the 24 month period. Mean monthly rainfall data $(\mathrm{mm})$ provided from the Blouberg Nature Reserve and monthly patterns of predation were summarised and analysed using a Fisher's Exact Test. The absolute number of game and livestock attacks occurring over the 24 month period was pooled together and categorised as occurring in the wet or dry season and analysed using a $\chi^{2}$ test. Count data was used in the temporal analysis to allow comparable results with other studies using a similar approach (Holmern et al. 2007; Michalski et al. 2006; Mponzi et al. 2014; Teichman et al. 2013). Furthermore, it was not possible to represent monthly losses as a proportion of total game and livestock holdings as accurate data on game numbers were not available and the number of livestock owned was calculated over annual rather than month long periods.

Maxent is an ecological niche model which uses a maximum entropy algorithm to determine the unknown distribution of a species over a geographical range, from a known sample of occurrence data and set of spatially explicit environmental conditions (Phillips and Dudík 2008; Phillips et al. 2004). We used it in an alternative context to measure the spatial risk of predation at finite scales. The input data for the Maxent Model refer to presence data (locational GPS points) where game and livestock were killed over a 24 month period in the study area and a set of raster maps (grid cells) detailing environmental and anthropogenic data covering the geographical area of interest. The Maxent Model outputs 'risk maps' predicting the probability of high and low risk areas where game and livestock attacks occurred across the Blouberg landscape according to specific environmental and anthropogenic conditions.

Threshold-independent methods were used to assess the performance of models. The area under the receiver operating characteristic curve (AUC) was used to measure how well the model predictions discriminated between locations where observations are present and absent (Phillips and Dudík 2008). AUC values ranging between 0.5 and 0.7 were considered poor models, between 0.7 and 0.9 were moderate and $>0.9$ were high performing models (Manel et al. 2001). Model performance was also assessed by testing whether the AUC value for the test data was significantly different to that of a random model (AUC $=0.5$ ) using a Mann-Whitney test based on 10 sensitivity values at each of the fractional 0.1 intervals of the predicated area from the Maxent omission output (Phillips et al. 2006) (further details are highlighted in the supplementary information, Online Resource 2).

\section{Results}

\section{Socio-economic characteristics of farming communities}

Commercial farmers included Afrikaans (89 \%) and Northern-Sotho (11\%) speakers who engaged in a range of commercial farming operations. One hundred percent of communal farmers were of Northern-Sotho origin. Ninety-five percent of all farmers were male and $5 \%$ were female as a consequence of the sampling strategy, which targeted household heads. 


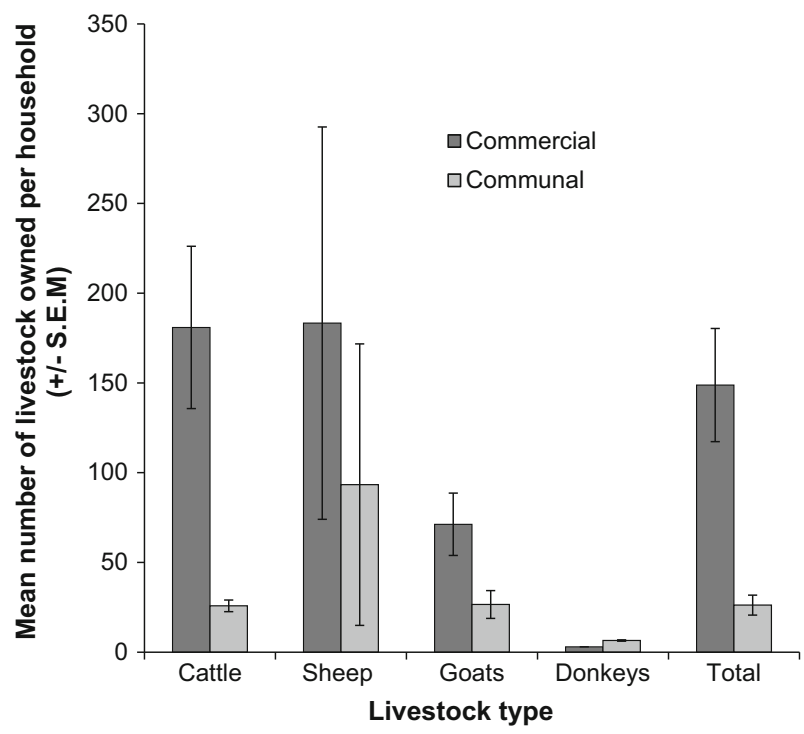

Fig. 2 Mean \pm SEM number of livestock owned per household on commercial and communal land from October 2009 to October 2011

Commercial farms in the Blouberg vary in size between 320 and 10,000 ha with an average size of 2694 ha. In contrast subsistence farming occurs on small, unfenced, fragmented plots of $<12$ ha close to village homesteads or communal arable lands. Fortyseven percent of commercial farmers engaged in crop farming and $53 \%$ of commercial farmers stated that crop farming was the biggest income generator, followed by game $(32 \%)$ and livestock $(16 \%)$. All commercial farmers in the Blouberg engaged in game farming to some extent stating it offered several forms of income including game capture (58\%), hunting (74\%) and eco-tourism (10\%).

Fifty-seven percent of commercial also engaged in the cattle farming industry. Few communal farmers $(8 \%)$ survived on an entirely subsistence lifestyle (agriculture and livestock) alone, the majority relied on pensions to enhance their income (61\%), followed by the sale of consumptive goods $(22 \%)$ and other employment opportunities (9\%). The mean number of livestock kept per household was 149 (SEM \pm 32 ) on commercial farms and $26(\mathrm{SEM} \pm 6)$ on communal land (Fig. 2).

\section{Impacts of game and livestock loss by leopards}

Sixty-six percent of reported attacks by large carnivores were based on indirect signs including bite marks on the carcass and the positioning of carcasses in the habitat (e.g. leopards kills stashed in trees), $26 \%$ through indirect signs such as spoor, $4 \%$ based on visual confirmation of the predator and $4 \%$ were unknown. Of 37 reported game attacks, leopards were the greatest cause of game loss $(89 \%)$, followed by cheetahs $(8 \%)$ and caracals $(3 \%)$ on commercial farms. Farmers reported that leopards predated on impala (28\%), nyala (24\%), warthog (21\%), ostrich (9\%), bushbuck (6\%), kudu (6\%), gemsbok $(3 \%)$ and waterbuck $(3 \%)$. 
On average, a significantly higher proportion of livestock were lost to predators compared to other causes of mortality on commercial farms (KWT: $\chi^{2}=24.3$, df $=3$, $\mathrm{P}<0.001)$ and communal land (KWT: $\left.\chi^{2}=19.4 \mathrm{df}=3, \mathrm{P}<0.001\right)$. Overall, livestock loss by predators represented $2.8 \%$ of the total livestock holdings recorded in the Blouberg during the study.

Leopards were implicated in 67 of 112 of reported livestock attacks (60\%), followed by brown hyaenas (19\%) jackals (12\%) and caracals (9\%). Leopards reportedly accounted for $87 \%$ of all cattle and $100 \%$ of all donkeys killed, with all of these predator attacks on young calves and foals ( $<3$ months of age). No incidents of leopard attacks on goats or sheep were reported. Of a total of 69 livestock attacks by leopards, $97 \%$ took place on free-ranging grazing herds and $3 \%$ took place in kraals; in all cases, shepherds and guardian dogs were not present during the time of attack.

Reported average financial losses per household per annum due to leopard predation on game was ZAR 2150 on commercial farms, compared to ZAR 10,807 for livestock on commercial farms, and ZAR 8775 on communal land. Leopard predation on nyala resulted in an average loss of ZAR 18,099 per household per annum (Table 1). Although we were not able to collect data on incomes for game farms, average annual incomes for white agricultural households were estimated at ZAR 460,357 for the Limpopo Province (Pauw 2005). The economic impacts of leopard predation on nyala thus represented $3.9 \%$ of the estimated annual income for commercial farmers. Leopard depredation on cattle resulted in an average loss of ZAR 12,183 per household per annum on commercial farms and ZAR 10,500 on communal land (Table 1). The majority of households in the Blouberg region have an estimated annual income of $<$ ZAR 18,000 per annum (Capricorn District Municipality, 2013-2014). Based on these income estimates, the average economic loss of cattle by leopards represented 2.6 and $58.3 \%$ of the estimated income on commercial farms and communal land, respectively. Leopard depredation on donkeys resulted in an

Table 1 Summary of the economic costs of livestock and game depredation by leopard in the Blouberg including the total economic cost, mean economic cost per household per annum, and mean $\%$ of the herd size (range) on commercial and communal land from October 2009 to October 2011

\begin{tabular}{llrrl}
\hline & $\begin{array}{l}\text { Livestock/Game } \\
\text { lost to leopard }\end{array}$ & $\begin{array}{l}\text { Total cost } \\
\text { (ZAR) }\end{array}$ & $\begin{array}{l}\text { Mean cost per household } \\
\text { per annum (ZAR) }\end{array}$ & $\begin{array}{l}\text { Mean \% of herd } \\
\text { size (range) }\end{array}$ \\
\hline Commercial & Cattle & 109,883 & 12,183 & $3(1-5)$ \\
& Donkeys & 700 & 700 & $25(0-25)$ \\
Total loss & & 110,583 & 12,883 & $28(1-30)$ \\
Communal & Cattle & 81,000 & 10,500 & $12.4(4-18)$ \\
& Donkeys & 5600 & 2800 & $42.5(25-60)$ \\
Total loss & & 86,600 & 13,300 & $54.9(29-78)$ \\
Commercial & Waterbuck & 2000 & 1000 & - \\
& Warthog & 4872 & 928 & - \\
& Gemsbok & 5167 & 2584 & - \\
& Ostrich & 5856 & 2928 & - \\
& Impala & 6246 & 2931 & - \\
& Kudu & 6810 & 3655 & - \\
& Bushbuck & 8608 & 4304 & - \\
\hline \multirow{2}{*}{ Total loss } & Nyala & 41,368 & 18,099 & - \\
\hline
\end{tabular}


average loss of ZAR 700 per household annually on commercial farms and ZAR 2800 on communal land (Table 1), representing 0.2 and $15.6 \%$ of the estimated income, respectively.

\section{Spatial patterns of leopard predation}

The risk of leopard predation on game was most significantly influenced by distance to water (percentage contribution $=70.6 \%$ ), followed by elevation $(16.8 \%$ ) and distance to nature reserves $(12.6 \%)$. The risk of leopard predation on game was highest close to water sources including the Brak River and the river channels on the Blouberg Mountain (Fig. 3a) and declined with increasing distance (Fig. 4a) and was also highest at low altitudes between 775 and $790 \mathrm{~m}$ and high elevations of the Blouberg Mountain between 900 and $920 \mathrm{~m}$ (Fig. 4b). The risk of leopard predation on game declined sharply as distance from the nature reserves increased (Fig. 4c).

The risk of leopard predation on livestock was most significantly influenced by distance to villages (contribution $=30.9 \%$ ), followed by distance to water $(23.3 \%)$, distance to roadways $(21.2 \%)$, distance to nature reserves $(15.4 \%)$ and elevation $(9.2 \%)$. The risk of leopard predation on livestock peaked at a distance of $3 \mathrm{~km}$ from the nearest village and decreased thereafter (Fig. 5a). It was highest close to water sources for example, the southeastern corner of the Blouberg Nature Reserve where the Brak River runs through the reserve (Fig. 3b) and declined with increasing distance from water (Fig. 5b) but increased beyond a distance of $8 \mathrm{~km}$ from roadways (Fig. 5c). The risk of a livestock attack by a leopard was highest close to the borders of nature reserves and decreased with increasing distance (Fig. 5d) with probability of attacks highest at low altitudes between 670 and $780 \mathrm{~m}$ and at the higher elevations of $1540-1760 \mathrm{~m}$ on the Blouberg Mountain (Figs. 3b, $5 \mathrm{e})$.

\section{Temporal patterns of leopard predation}

There was a significant seasonal variation in the number of game and livestock killed on commercial farms and the number of livestock on communal land by leopards (Fisher's Exact Test: $\mathrm{P}<0.001$ for all tests), with the highest kills in September (supplementary information, Online Resource 3). Seventy percent of commercial cattle farmers and $81 \%$ of communal cattle farmers reported that calving and game births peak in September and extend into January. A significantly higher number of game species were killed by leopards in the dry compared to the wet season on commercial farms (CST: $\chi^{2}=4.2$, df $=1$, $\mathrm{P}=0.040$ ) (supplementary information, Online Resource 4). The number of livestock killed by leopards during the dry season was significantly higher on communal land compared to commercial land (CST: $\chi^{2}=7, \mathrm{df}=1, \mathrm{P}=0.008$ ) (supplementary information, Online Resource 4).

\section{Qualitative data}

\section{Impacts of game and livestock predation by leopards}

Ethnographic observations of the value of game species among farmers revealed mainly economic considerations. Expensive game and rare species such as buffalo (Syncerus caffe), black rhino (Diceros bicornis), sable antelope, and endangered roan antelope 
(a)

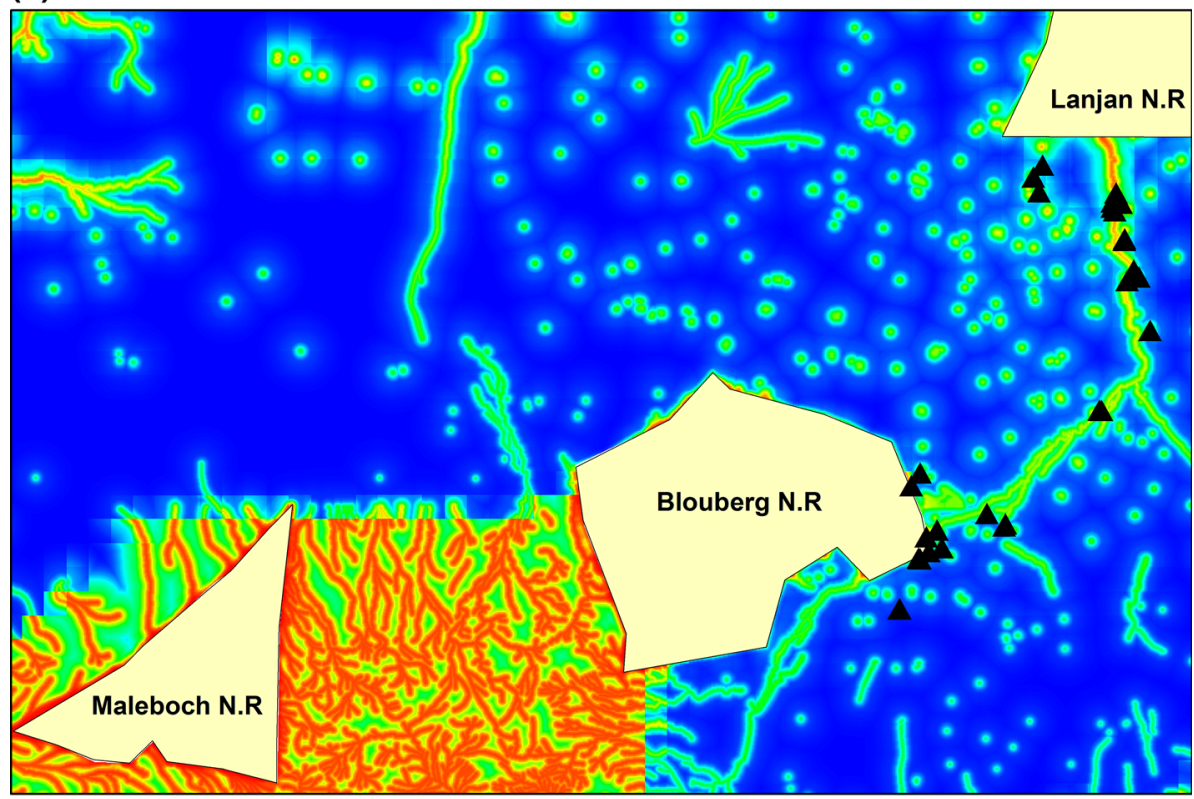

(b)

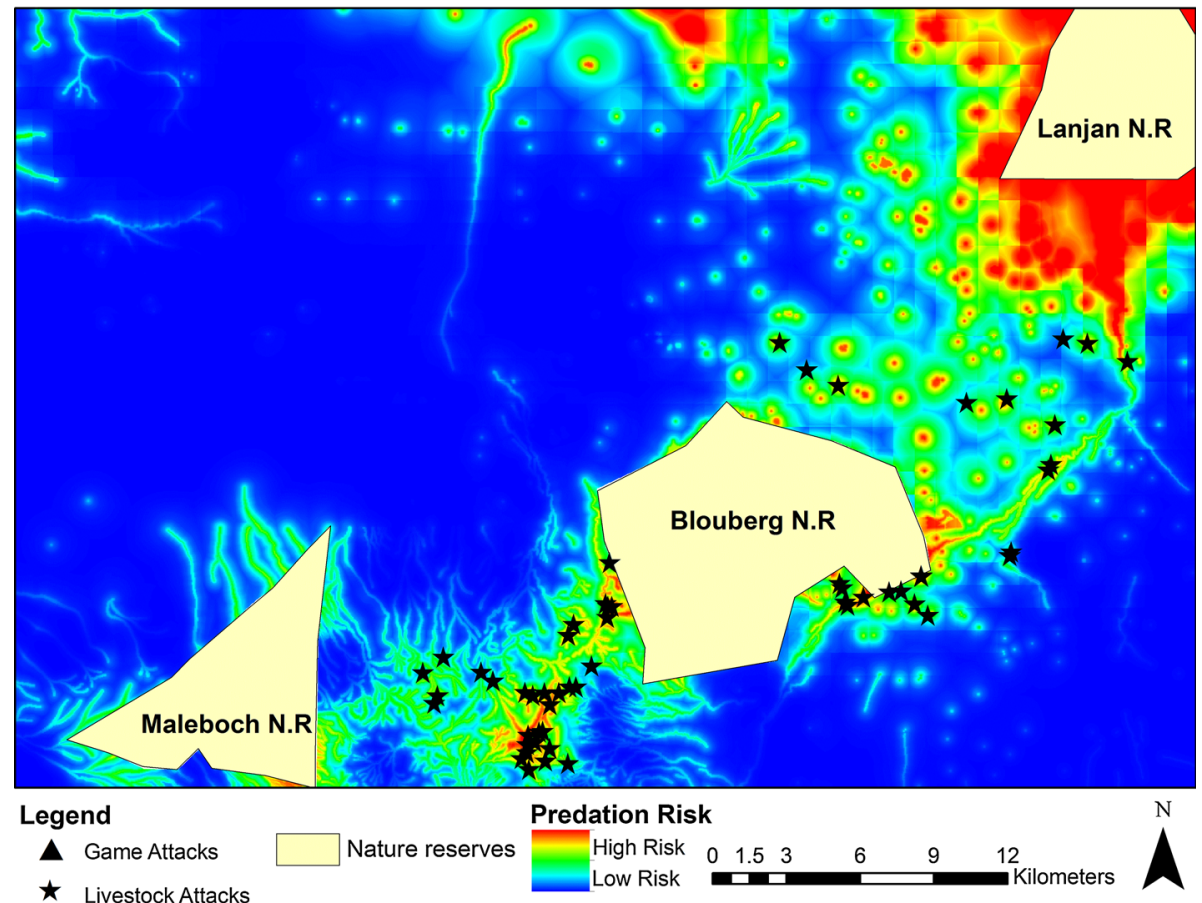

Fig. 3 Predicted areas of high-low predation risk for $\mathbf{a}$ game attacks and $\mathbf{b}$ livestock attacks by leopards in the Blouberg Mountain Range 

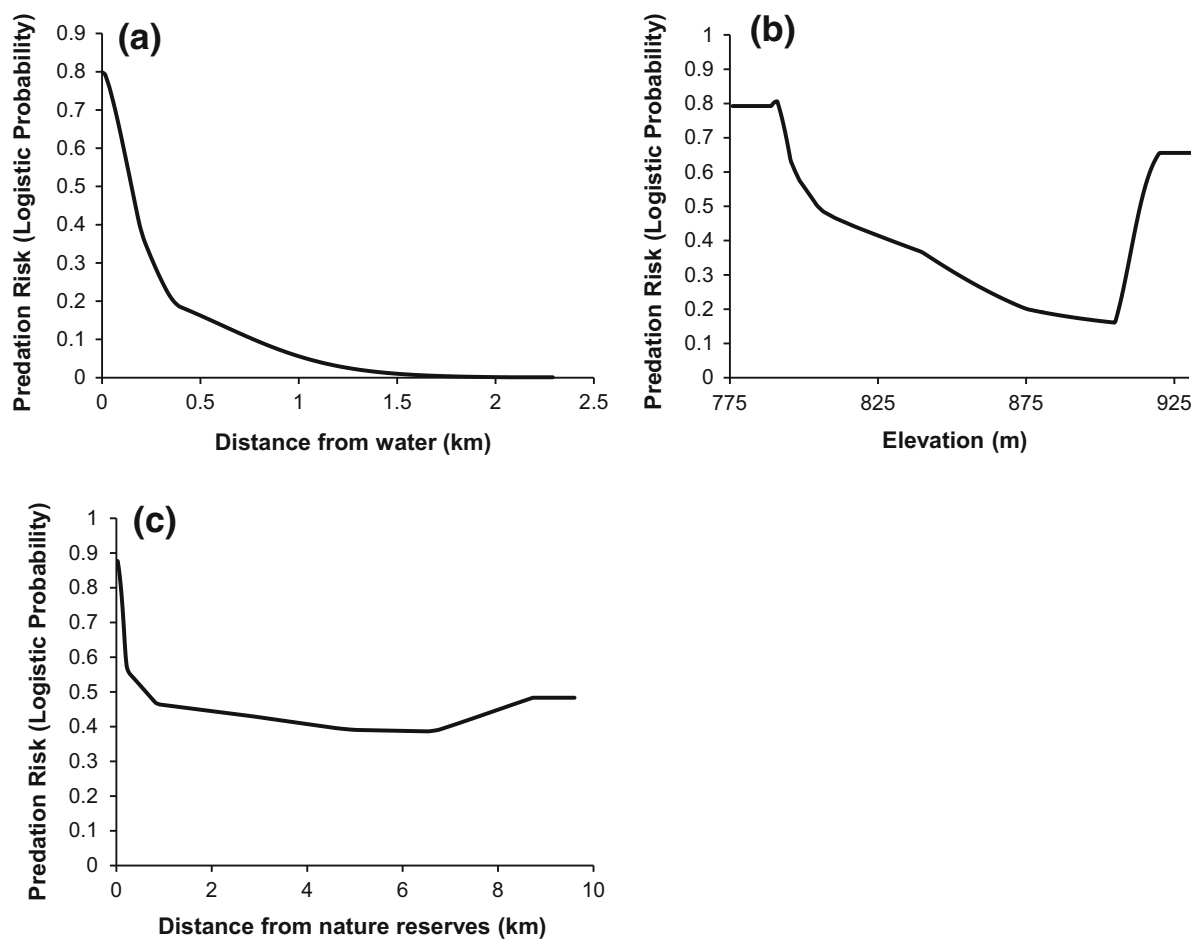

Fig. 4 Relationships between predation risk on game and a distance to water $(\mathrm{km})$, $\mathbf{b}$ elevation $(\mathrm{m})$ and c distance to nature reserves $(\mathrm{km})$

(Hippotragus equinus) were sold as profitable species to other game farmers for hunting and to conservation agencies for reintroduction programmes. All species predated on by leopards were valued economically for trophy hunting, bow hunting and biltong hunting. Commercial farmers utilised and valued livestock primarily for their economic value by selling cattle at auctions and to supply the meat and biltong industry.

Communal farmers used livestock an insurance fund during times of economic hardship to generate finances for immediate needs such as paying for food and household necessities. Wealthier families may sell livestock to meet education expenses or to finance business ventures and in very rare cases for bride wealth payments. Livestock were also used for milk, the skins were used to decorate the interior of households and dung was applied to build and protect houses. Donkeys were used as a form of transportation and as draught animals to plough agricultural fields. Cattle represented the highest form of sacrifice in Sotho culture to appease or ensure success with ancestral spirits and as a means of obtaining health, prosperity and happiness. Livestock depredation was perceived by one communal farmer as the loss of an important spiritual resource:

When you lose one of your cattle, it's not just about the money you could lose, but also those cultural things you lose alongside it. We slaughter cattle and goats, as gifts to our ancestors. When we are having hard times we slaughter a cow, to help that situation. Our livestock are gifts for the ancestors they help us to keep a good relationship together. Without those things, our relationship could get worse, and bad things might happen because we can't make the ancestors happy. 

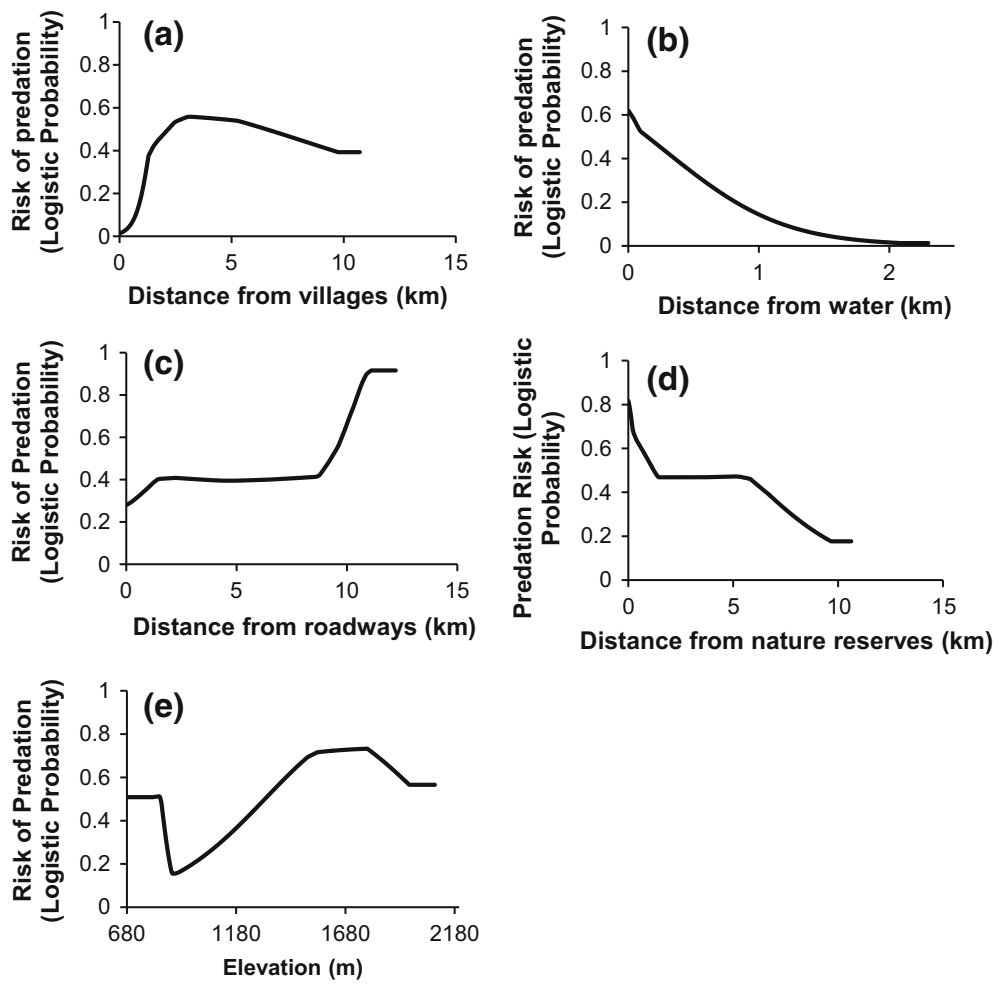

Fig. 5 Risk of predation on livestock and a distance to village $(\mathrm{km})$, $\mathbf{b}$ distance to water $(\mathrm{km})$, $\mathbf{c}$ distance to roadways $(\mathrm{km})$, $\mathbf{d}$ distance to nature reserves $(\mathrm{km})$ and e elevation $(\mathrm{m})$

Cattle were loved by their owners. In some instances communal farmers referred to cattle as their "children" and associated cattle losses with feelings of diminished wellbeing. Similarly, commercial farmers expressed feelings of diminished wellbeing when articulating their thoughts about livestock losses. A commercial farmer said: "It's sad on our farm to see an attack on one of our stock. We put a lot of hard work and time into rearing that animal and you just feel it's a bit of a waste." The loss of cattle was perceived by several farmers as a cause of cultural decay on communal land. An elderly communal farmer explained:

Cattle are part of our culture, since we were born and before us we had lots of cattle, but those predators killing our cattle are also killing our culture.

Similarly, another communal farmer stated:

These days we farmers do not own as many cattle as we had before, the younger generation are no longer interested in staying in these rural areas and keeping livestock.

\section{Locally-adapted management strategies}

Some game farmers protected expensive rare game species such as buffalo, black rhino, sable antelope and endangered roan behind electrified fences from predators and did not 
report any forms of predation by leopards. Some commercial farmers described a variety of strategies to manage depredation on livestock including: grazing cattle away from known leopard habitats, kraaling calves close to the homestead and reducing hunting on game species to divert the risk of predation away from livestock. A commercial farmer described several of these methods on his farm:

I decided to change my management strategy after I lost seven calves in several months, a few years ago. I started to create specific areas for the leopard to occupy, that had water and plenty of game. I stopped shooting so many impala to ensure the leopard had enough prey. I kept the cattle away from the bushy areas, kept the calves close to my home at night and expanded the farm to include grazing for cattle amongst the crop areas, which were too open for the leopard.

The avoidance of predation areas and improving habitats for leopards was supported by only a subset of commercial farmers (32\%). Other commercial farmers identified the high economic costs required to alter their land management strategies and expressed concerns that habitat improvements would increase leopard numbers and predation on game. In contrast, no communal farmers applied strategies to manage habitats and resources to limit depredation on livestock on communal land. Although, some communal farmers reestablished rotational grazing systems to improve the condition of grazing land on communal land, both farming communities expressed a need for educational workshops facilitated by outside agencies to provide expertise and guidance to implement these strategies.

During the dry season, communal farmers grazed livestock away from villages on the Blouberg Mountain in search of high quality pastures, often leaving livestock unattended and vulnerable to attack. An elderly communal farmer explained:

The only grass available during this time is on the mountain. Grazing is too scarce and the cattle are travelling a long distance to search for pasture, like now this loose hay is too dry. That is the time for the predators. Every time this year, we know we are risking, grazing up there. But we have no other choice.

Livestock were free-grazing and mixed with other livestock herds and many cattle gave birth in the mountain environment during the dry season thereby, increasing the vulnerability of calves to leopard attacks in the mountain.

Degradation of the communal land was often associated with the forced re-settlement and overpopulation of Northern-Sotho speakers into the Bantustans (ten distinct territories where people were grouped according to their ethnic background) during apartheid, which decreased the availability of land and promoted its segregation. A communal farmer stated:

When they moved us long ago we we forced to live in a different way, we couldn't use lots of land for grazing and moving around between seasons, there were too many living together. Since then the land has been bad. It gets worse with other things like floods and droughts which happen now.

Traditionally, livestock management roles were fulfilled by young males who progressed through several stages of herding and took on greater responsibility for livestock as they grew older (supplementary information, Online Resource 5). In the past, young boys would forego an education to look after livestock but many parents now recognise the importance of education. Currently, younger generations do not share ambitions to own livestock and instead seek further education and employment opportunities in the cities. This results in the erosion of traditional practices and the declining labour force, shifting the 
responsibility onto elderly men. Communal farmers perceived the elderly to be exposed to increased health risks due to the need to travel long distances to the mountain in the dry season.

Economic concerns related to the labour costs of protecting livestock also prevented both farming communities from employing shepherds, livestock-guardian dogs and kraaling livestock. Forty-eight percent of communal farmers claimed that shepherding and the employment of livestock guardian dogs was costly, because the cost of employing a single full-time shepherd (ZAR 604 per month) constrained the economic security of local livelihoods (assuming annual incomes are $<$ ZAR 18,000) (Capricorn District Municipality, 2013-2014). In contrast, $74 \%$ of commercial farmers perceived livestock guarding and shepherding as affordable.

Seventy-four percent of commercial farmers did not support kraaling cattle as a feasible strategy to mitigate conflict. A commercial farmer stated:

We run a tight ship on these farms, if we kraaled them all at night we would lose productivity. They would lose weight, we can't afford that. There's also the problem with time. It takes a long time to find the cattle and get them drawn into the kraals at night.

Communal farmers $(65 \%)$ were supportive of kraaling because it forms part of traditional practices and materials for the construction of kraals are procured locally without economic cost. Some communal farmers also expressed concerns that kraaling was labour intensive for elderly farmers.

\section{Discussion}

\section{Impacts of game and livestock loss by leopards}

In South Africa and in other countries there is a lack of published data on reported predation rates of leopards on game. Leopards accounted for $89 \%$ of attacks compared to other large carnivores in the Blouberg, which is higher than predation rates of $40 \%$ by leopards in the Waterberg Plateau of South Africa (Thorn et al. 2013) and $32 \%$ on game ranches in Botswana (Boast 2014). Leopards mainly preyed on nyala calves, warthog and impala which fall within the preferable prey size for leopards of 10-40 kg (Hayward et al. 2006). These species had the highest relative abundance index on commercial farms in the Blouberg compared to other prey species predated on by leopards (Constant 2014).

Livestock depredation by large carnivores constituted the greatest form of reported losses in the Blouberg region. Levels of loss were similar to those reported in the NorthWest Province of South Africa, (Thorn et al. 2012) and $2.2 \%$ in Botswana (Schiess-Meier et al. 2007), but this finding contrasts with other studies on large carnivores where natural causes of mortality predominate (Dar et al. 2009; Hemson et al. 2009). Leopards accounted for $60 \%$ of livestock attacks in the Blouberg, much higher than other regions in South Africa such as the Waterberg (Thorn et al. 2012) although in line with similar rates reported in Botswana (Schiess-Meier et al. 2007). Leopards in the Blouberg predate on young calves and donkey foals similarly, $64 \%$ of reported depredation by leopards in the neighbouring Soutpansberg Mountains occurred on young calves (Chase-Grey 2011).

There is a lack of comparable data on the economic costs of depredation for specific game species by leopards in South Africa and in other countries. Average annual losses for game per household by leopards on commercial farms were ZAR 2150 which was 
considerably lower than average estimates in the Waterberg region of ZAR 8994 per annum (Swanepoel 2008). Scaling our results from a site area of 40, 000 ha to the 150, 000 ha in the Waterberg produces an estimated cost of ZAR 8062 per annum, which is broadly in line with the Waterberg estimate (Swanepoel 2008). The estimated annual loss for nyala per household was remarkably high compared to other game species, but represented a relatively small proportion of the estimated annual income (ZAR 460,357) for a commercial farmer $(3.9 \%)$.

The total economic livestock loss was higher on commercial farms compared to communal land, probably owing to the more expensive farming breeds such as Bonsmara owned by commercial farmers. Cattle depredation by leopards resulted in an average loss per household per annum of ZAR 12,183 on commercial farms and ZAR 10,500 on communal land, whilst cattle losses by leopards in the Waterberg was considerably lower at ZAR 2465 per annum (Swanepoel 2008). However, Swanepoel (2008) reported that actual levels of livestock predation in leopard scats were comparatively low in the Waterberg and the proportion of game ranches in the study area (75\%) was higher than the presence of livestock farms. Therefore, our higher economic losses may relate to the high number of livestock farms surveyed in the Blouberg.

Hill (2004) suggests that quantification of the extent and impacts of livestock loss at the community level provides insights into the severity of the conflict problem for the general population, but, the impacts may not be uniform for individuals or households. When considering average and extreme economic values at the household level, the average economic costs for communal households represented a significant proportion of average annual incomes for communal farmers of 58 and $16 \%$ for depredation on cattle and donkeys, respectively. In many cases, most households own $<$ ZAR 18,000 making the percentage costs much higher compared to those experienced by commercial farmers. In extremes cases, donkey losses represented between 25 and $60 \%$ of the total donkey stock for communal farmers.

People dependent on a single livelihood strategy are more vulnerable to the impacts of depredation, because the social and economic impacts of wildlife damage are intensified (Dickman 2010). Wealth, income diversification and social reciprocity within families and communities may provide adequate coping mechanisms for buffering the impacts of damage-causing animals (Naughton-Treves et al. 2005). Predation by leopards represents greater economic costs for communal farmers who rely on cattle and donkeys for subsistence and functional uses, whilst those who earn an additional income from pension grants, entrepreneurial activities and other employment provide additional reserves to cope. Traditional forms of livestock acquirement and sharing have eroded due to the changing economic status of livestock in communal areas, reducing the ability of poorer households to cope with the impacts of livestock depredation (Constant 2014). In contrast, economic impacts for commercial farmers are less severe because farmers own larger livestock herds and the majority of households diversify their income by engaging in crop and game farming industries to buffer the impacts of depredation on cattle.

The hidden impacts of depredation relate to "costs uncompensated, temporally delayed, psychological or social in nature" (Barua et al. 2013, p. 311). This study contributes further to the literature by acknowledging a range of other hidden impacts caused by livestock depredation such as a loss of social capital for communal farmers because livestock are sometimes used to finance funerals, bride wealth and provide households with additional revenue. Livestock loss can also induce hidden costs because people attach emotional and cultural significance to livestock (Dickman 2010). Livestock loss for both farming communities causes a sense of diminished wellbeing amongst both farming groups. For 
communal farmers hidden costs translate into a loss of a spiritual resource and perceived cultural decay.

\section{Spatial patterns of leopard predation}

The spatial risk of predation on game was primarily influenced by ecological factors linked to leopard ecology with close proximity to water most influencing the risk of predation. In contrast the spatial risk of livestock predation was most influenced by human factors with increasing distance from villages and social factors linked to the adoption of livestock guarding strategies. Proximity to streams was an important predictor for game and livestock depredation in the Blouberg and other studies have shown that distance to water is an important criterion for leopard habitat selection (Simcharoen et al. 2008). Such landscape features may provide adequate hunting grounds or attract a high abundance of prey species for leopards (Karanth and Sunquist 2000; Stephens and Krebs 1986) and higher rates of predation on livestock have been reported by jaguars in the Amazon closer to riparian waterways (Michalski et al. 2006). The perennial Brak River and river channels flowing through the Blouberg Mountain may thus be attractive for leopards and their prey because they offer drinking water, are interspersed by forest providing cover for leopards to stalk their prey. Camera traps showed that leopards use these areas as corridors for movement (Constant 2014).

Proximity to nature reserves was moderately important for predicting game and livestock depredation with the greatest risk close to the borders of reserves where high leopard densities (5.4 leopards per $100 \mathrm{~km}^{2}$ ) have been recorded inside protected areas compared to non-protected areas (0.7 leopards per $100 \mathrm{~km}^{2}$ ) (Constant 2014). Similar results have been suggested for other studies in South Africa where distance to protected areas influences predation rates by large carnivores (Thorn et al. 2012). Risk of predation was greatest at low altitudes (Game: 775-790 m Livestock: 670-780 m) and at high altitudes (Game: 900-920 m Livestock: 1540-1760 m) reflecting differences in surface ruggedness between land use types and livestock husbandry practices. The lowest altitudes were associated with a higher leopard predation risk on commercial farms where managed game and livestock populations were grazed on lower-lying regions and the higher altitudes on the Blouberg Mountain where livestock and game grazed on communal land. Surface ruggedness is an important predictor of the suitability of leopard habitats in South Africa (Swanepoel et al. 2012). Mountainous areas are often preferred habitat for leopards because they offer refugia from human persecution, other predators and to avoid kleptoparasitism (Gavashelishvili and Lukarevskiy 2008; Norton et al. 1986). High elevations was also an influential factor driving leopard predation in the Waterberg, Limpopo Province (Thorn et al. 2013).

The spatial locations of leopard attacks on livestock were most influenced by distance to villages, with a higher predation risk further away from villages. In Laikipia District, Kenya, the risk of predation on cattle by leopards declined when more people were present (Ogada et al. 2003). The risk of predation on livestock increased with increasing distance from roadways, a pattern which has also been observed for puma attacks on domestic livestock in central Mexico (Zarco-González et al. 2012). The spatial risk of livestock depredation by leopards on communal land is largely associated with a lack of local investment in livestock guarding strategies and temporal changes in livestock management strategies.

Inadequate livestock guarding practices have also been cited by numerous researchers as a significant contributor to livestock attacks by predators (Sangay and Vernes 2008; Wang and Macdonald 2009). However, few studies have identified the underlying social factors influencing their adoption. Traditional management livestock strategies have eroded in the 
Blouberg due to the perceived economic costs of their implementation and the migrant labour system shifting the responsibility of shepherding tasks onto the elderly. Access to labour and income generation constrained the ability of communal farmers to employ fulltime shepherds and to afford materials to improve livestock husbandry practices. Commercial farmers were unlikely to support mitigation strategies which compromised the productivity of farms, negatively impacted livelihoods and were time-consuming to implement. Communal farmers were disinclined to support initiatives that were unfamiliar, compared to those that built on traditional knowledge systems. Both farming communities identified a lack of knowledge as constraining their ability to implement certain strategies.

The Blouberg Municipality is one of the most marginalised municipalities in the Capricorn District which is further accentuated by high levels of poverty, a lack of infrastructural development and education and social stratification of families caused by the migrant labour system (Blouberg Local Municipality 2013-2016). Large numbers of men and children seek work and educational opportunities in the cities (Blouberg Local Municipality 2013-2016). The impacts of the migrant labour systems have altered the roles and responsibilities for livestock management and introduced opportunity costs for elderly communal farmers due to the health risks associated with shepherding and protecting livestock during the dry season.

\section{Temporal patterns of leopard predation}

Our study reveals that there is a clear seasonal variation in depredation peaks on game and livestock which are related to the annual peak calving season for game and livestock species, with both peaks co-occurring at the end of the dry season. Similar findings have been observed by jaguars in the Amazon (Michalski et al. 2006; Palmeira et al. 2008). The number of game attacks occurring during the dry season was significantly higher than during the wet season. This may be due to seasonal changes in water supply associated with game farms. Risk of game predation in the Blouberg was highest close to water sources however, the perennial Brak River which provides the main water supply for game is dry in summer and game must seek alternative drinking areas. Although, a temporal relationship between risk of predation and bio-physical factors was not explored it is possible that attacks on game may have increased during the dry season because artificial bodies of water on game farms may have attracted game and facilitated higher rates of predation by leopards. Similar findings have been observed for lions in Kenya where attacks increased close to water sources during the dry season (Kays and Patterson 2002).

The number of livestock attacks occurring during the dry season was significantly higher on communal land compared to commercial farms which may relate to a lack of water in lower-lying regions and land degradation in communal areas influencing seasonal grazing patterns and the availability of wild prey. Land degradation in communal areas in South Africa has historical roots. In the 1970s promotion of the Bantustan system in during apartheid rule resulted in the resettlement of Northern Sotho speakers into the Lebowa Bantustan (Ramphele 1991). From the 1930s to 1980s the government initiated the betterment programmes in the Bantustans to maximise agricultural production by demarcating land into arable, residential and common grazing areas (Ramphele 1991). Throughout South Africa, poverty, overpopulation and the small size of family holdings led to destructive land use practices, including deforestation and the removal of dung from the veld in the Bantustans (Ramphele 1991). The poor conditions in the Bantustans caused the men to migrate to the cities in search of wage labour and to seek alternative incomes on surrounding farms (Beinart 2008). During this time, the Bahananwa were perceived by the 
local government as rebellious on account of their refusal to cooperate with the new apartheid laws and were punished by the starving the Bahananwa of basic infrastructure and developmental needs making it one of the least developed regions in the present-day Limpopo Province (Blouberg Local Municipality 2007-2008). The former fences and water systems created by the Betterment Programme have been destroyed by villagers (Grwambi et al. 2006). The over-grazing of livestock on the mountain plateau and communal areas contribute to the erosion of peatland and wetland areas, which dries up important waterways supplying lower-lying regions (Egan 2007). During the dry season, the condition of grazing land close to villages is poor, because of a lack of rain, overgrazing and high stocking rates of livestock (Grwambi et al. 2006). These additive effects have contributed to the degradation of the grazing land and lack of water supplies in the communal areas during the dry season.

Leopard occupancy on communal land is also significantly lower compared to commercial farms due to a lower wild prey biomass potentially caused by overhunting of wild game for bushmeat and traditional medicine, and habitat conversion caused by overgrazing and the felling of trees for firewood (Constant 2014). High stocking densities of livestock on open rangelands in the Trans-Himalayas, India, compete with wild prey for common resources leading to a decline in the abundance of wild prey and large carnivores to predate on livestock (Bagchi and Mishra 2006; Mishra et al. 2003). Similar relationships may also be observed on communal land in the Blouberg where a lack of natural prey causes a shift in the dietary requirements of leopards on livestock.

The shift in land use from pastoralism to game farming has been identified as a growing trend in South Africa since the 1980s (Grossman et al. 1999). Commercial farms occupy large areas of land and may function as 'attractants' for leopards in the Blouberg as Constant (2014) showed that leopard occupancy is significantly higher on commercial farms compared to communal land due to the higher availability of wild prey species. Similar results have been documented for clouded leopards in Thailand, where site occupancy is dependent on the presence of preferred prey species (Ngoprasert et al. 2007; Steinmetz et al. 2013). However, long-term data on the population dynamics and feeding ecology of leopards and their prey would need to be collected to confirm this hypothesis.

\section{Management of human-leopard conflict: Implications for farming livelihoods and leopard conservation}

Game farms provide $80 \%$ of nature conservation activities in South Africa on privately owned land (Eloff 2001; Fox and Du Plessis 2000). Game farms are thus important conservation areas for leopards outside protected areas because they support a high abundance of naturally occurring game species (Chase-Grey et al. 2013). However, Constant (2014) also found that commercial farms in the Blouberg function as "ecological traps" because they can represent areas with disproportionate mortality due to the application of lethal control measures in response to game attacks, for land that otherwise provides suitable resources for leopards. The management of game attacks by leopard are difficult to control because game species are largely free-ranging on farms in such cases, game farmers should avoid purchasing expensive game such as nyala. However, on several farms predation on rare game breeds was managed by securing game inside electrified fences which may serve to limit depredation by leopards on expensive species.

Some commercial farmers have employed strategies to improve habitats and game numbers for leopards on their farms as a strategy to divert leopard hunting pressure away from livestock. Similarly, a lack of wild prey on communal land may also enhance 
livestock depredation. However, when wild prey are abundant, depredation on livestock species may be high, because carnivores spend more time in prey rich environments where encounter rates with livestock are high (Moa et al. 2006). In areas, where livestock are perceived as alternative prey, they may also be killed when wild prey are less abundant (Woodroffe et al. 2007). Further research on the population ecology of leopards and their prey, and the composition of leopard diets before and after the introduction of this strategy are necessary for evaluating its success. In turn, prohibition of illegal lethal control measures and raising farmer's tolerance for attacks on game will be important.

Traditional livestock management strategies need to be revitalised to protect livestock from leopards. The high labour costs of shepherding can be overcome by developing a communal fund to employ shepherds, and collaborating with other farmers to construct communal kraals on the mountain. The employment of shepherds and livestock-guardian dogs is necessary to protect livestock from predators when grazed far away from areas of human settlement; to guide livestock away from the borders of nature reserves and to protect them at water points. The construction of communal kraals to pen in livestock at night and sleeping huts for night-time guards on the mountain during the dry season may also prevent livestock attacks. Synchronising breeding seasons during the wet season, constructing artificial water points close to villages on communal land, and employing rotational grazing systems to improve the quality of grass in communal areas mitigates against the need to graze livestock far away from local households during the dry season.

Mitigation strategies, which raise people's tolerance for wildlife require explicit incentives for improving tolerance and sanctions imposed for retaliatory behaviours such as incentive and education schemes (Mishra 1997). Biodiversity stewardship programmes in South Africa ensure that private and communally owned areas with high biodiversity value receive secure conservation status, expand biodiversity conservation areas and ensure landowners receive tangible benefits for their conservation actions and become empowered decision makers (Paterson 2009). Income tax incentives are granted to landowners who forego development opportunities on their land in the interests of biodiversity conservation. The Limpopo Department of Agriculture, through their Expanded Public Works Programme creates work opportunities for the unemployed to participate on projects to improve local environments (Republic of South Africa 2013). Such approaches may encourage landowners to improve game and livestock management practices for example, improving habitats for leopards and grazing land for farmers. The success of these approaches depends on the collaborative efforts of outside agencies to provide expertise and advice, and to assist in decentralising responsibility and action at the local level.

\section{Interdisciplinary research approach: applications for human-wildlife conflict}

The results of this study advocate the need for researchers to recognise the importance of local knowledge and expectations for informing the research and planning of locally relevant mitigation strategies, alongside scientific judgements. Researchers should incorporate the priorities of their interviewees to inform the design of human-wildlife conflict studies at the pilot stage. Such approaches will ensure that relevant issues are addressed to the people most affected by wildlife. The interdisciplinary research methodology adopted in this study could be applied to other studies intended to evaluate the impacts, characteristics and management of human-wildlife conflict by drawing on multiple-methods to gather social and ecological data in situ and extending analyses to include qualitative and quantitative approaches. Other researchers would benefit from the flexibility of the 
research approach by saving time and resources, as a tool to bring together different knowledge systems, incorporate local priorities and identify new topics for enquiry. This allows for the collection of nuanced contextual and rich data and continual verification of the data according to what is 'seen' and 'heard' and allows data to be set within important historical, cultural and social contexts. Such approaches have implications for researching contentious subjects such as illegal behaviour and the application of lethal control measures.

Acknowledgments This worked was funded by an ESRC-NERC interdisciplinary studentship. Due to ethical concerns, supporting data cannot be shared because respondents did not give informed consent to make their data openly available. We thank Dr Ian Gaigher, Limpopo Department of Economic Development, Environment and Tourism (LEDET), Blouberg Municipality, Blouberg Tribal Authority and the Bro Brak Farmers Association for supporting and participating the study and providing logistical support. We are most grateful to LEDET and the Council of Geoscience for providing GIS data and maps for the study. We also thank Calvin Leboho for acting as an interpreter throughout the study.

\section{Compliance with ethical standards}

Conflict of interest The authors declare that they have no conflict of interest.

Ethical approval All fieldwork was approved by the Life Sciences Ethical Review Process Committee and the Department of Anthropology Ethics Committee at Durham University, UK. All work was conducted with approved permits from LEDET in South Africa. Informant's oral agreement to participant in the study was taken as informed consent.

Open Access This article is distributed under the terms of the Creative Commons Attribution 4.0 International License (http://creativecommons.org/licenses/by/4.0/), which permits unrestricted use, distribution, and reproduction in any medium, provided you give appropriate credit to the original author(s) and the source, provide a link to the Creative Commons license, and indicate if changes were made.

\section{References}

Abade L, Macdonald DW, Dickman AJ (2014) Using landscape and bioclimatic features to predict the distribution of lions, leopards and spotted Hyaenas in Tanzania's Ruaha Landscape. PLoS ONE 9:e96261. doi:10.1371/journal.pone.0096261

Bagchi S, Mishra C (2006) Living with large carnivores: predation on livestock by the snow leopard (Uncia uncia). J Zool 268:217-224

Balme GA, Hunter LT, Goodman P, Ferguson H, Craigie J, Slotow R (2010) An adaptive management approach to trophy hunting of leopards Panthera pardus: a case study from KwaZulu-Natal, South Africa. In: Biology and conservation of wild felids. Oxford University Press, Oxford, pp 341-352

Barua M, Bhagwat SA, Jadhav S (2013) The hidden dimensions of human-wildlife conflict: health impacts, opportunity and transaction costs. Biol Conserv 157:309-316

Beinart W (2008) The rise of conservation in South Africa: settlers, livestock, and the environment 1770-1950. Oxford University Press, Oxford

Blouberg Local Municipality (2007-2008) Integrated Development Plan

Blouberg Local Municipality (2010-2011) Blouberg Municipality Annual Report 2010/2011

Blouberg Local Municipality (2013-2016) Integrated Development Plan

Boast LK (2014) Exploring the causes of and mitigation options for human-predator conflict on game ranches in Botswana: how is coexistence possible? PhD Thesis, University of Cape Town, South Africa

Chase-Grey J (2011) Leopard population dynamics, trophy hunting and conservation in the Soutpansberg Mountains, South Africa. PhD Thesis, Durham University, Durham

Chase-Grey JN, Kent VT, Hill RA (2013) Evidence of a high density population of harvested leopards in a montane environment. PLoS ONE 8(12):e82832. doi:10.1371/journal.pone.0082832

Constant N (2014) A socio-ecological approach towards understanding conflict between leopards (Panthera pardus) and humans in South Africa: implications for leopard conservation and farming livelihoods. Durham University, Durham 
Dar NI, Minhas RA, Zaman Q, Linkie M (2009) Predicting the patterns, perceptions and causes of humancarnivore conflict in and around Machiara National Park. Pak Biol Conserv 142:2076-2082

Dickman AJ (2010) Complexities of conflict: the importance of considering social factors for effectively resolving human-wildlife conflict. Anim Conserv 13:458-466. doi:10.1111/j.1469-1795.2010.00368.x

Drury R, Homewood K, Randall S (2011) Less is more: the potential of qualitative approaches in conservation research. Anim Conserv 14:18-24

Egan V (2007) A report on the conservation of the Blouberg and Makgabeng Plateau

Eloff T (2001) The economic realities of the game industry in South Africa. In: Sustainable utilisationconservation in practice. In: Proceedings of the 5th international wildlife ranching symposium

Emerson RM, Fretz RI, Shaw LL (1995) Writing ethnographic fieldnotes. University of Chicago Press, Chicago

Emerson RM, Fretz RI, Shaw LL (2011) Writing ethnographic fieldnotes. University of Chicago Press, Chicago

Fox T, Du Plessis P (2000) Hunting in southern Africa. Afr Indigo 3:40-47

Gavashelishvili A, Lukarevskiy V (2008) Modelling the habitat requirements of leopard Panthera pardus in west and central Asia. J Appl Ecol 45:579-588

Grossman D, Holden P, Collinson R (1999) Veld management on the game ranch. University of Natal Press, Pietermaritzburg

Grwambi B, Kolanisi U, Maine N, Mphahlele K, Raidimi N, Ramaifo K (2006) Livelihoods in the rural areas of Blouberg municipality (Gemarke and Early Dawn villages), Limpopo Province, South Africa: opportunities for commercialising livestock production in the communal land use system. Wageningen, ICRA-ARD Report

Hayward M, Henschel P, O’Brien J, Hofmeyr M, Balme G, Kerley G (2006) Prey preferences of the leopard (Panthera pardus). J Zool 270:298-313

Hemson G, Maclennan S, Mills G, Johnson P, Macdonald D (2009) Community, lions, livestock and money: a spatial and social analysis of attitudes to wildlife and the conservation value of tourism in a humancarnivore conflict in Botswana. Biol Conserv 142:2718-2725

Henschel P (2008) The conservation biology of the leopard Panthera pardus in Gabon: status, threats and strategies for conservation. Dissertation, Göttingen University

Hill CM (2004) Farmers' perspectives of conflict at the wildlife-agriculture boundary: some lessons learned from African subsistence farmers. Hum Dimens Wildl 9:279-286

Holmern T, Nyahongo J, Røskaft E (2007) Livestock loss caused by predators outside the Serengeti National Park, Tanzania. Biol Conserv 135:518-526

Inskip C, Zimmermann A (2009) Human-felid conflict: a review of patterns and priorities worldwide. Oryx 43:18-34

Karanth KU, Sunquist ME (2000) Behavioural correlates of predation by tiger (Panthera tigris), leopard (Panthera pardus) and dhole (Cuon alpinus) in Nagarahole, India. J Zool 250:255-265

Kays RW, Patterson BD (2002) Mane variation in African lions and its social correlates. Can J Zool 80:471-478

Limpopo Provincial Government (2004) Blouberg Nature Reserve Management Plan

Lindsey P, Romanach S, Romanach S, Davies-Mostert H (2009) A synthesis of early indicators of the drivers of predator conservation on private lands in South Africa. In: Hayward M, Somers M (eds) Reintroduction of top-order predators. Wiley-Blackwell, London, pp 321-344

Manel S, Williams HC, Ormerod SJ (2001) Evaluating presence-absence models in ecology: the need to account for prevalence. J Appl Ecol 38:921-931

McGranahan C (2015) What is ethnography? Teaching ethnographic sensibilities without fieldwork. Teach Anthropol 4:23-36

Michalski F, Boulhosa R, Faria A, Peres C (2006) Human-wildlife conflicts in a fragmented Amazonian forest landscape: determinants of large felid depredation on livestock. Anim Conserv 9:179-188

Mishra C (1997) Livestock depredation by large carnivores in the Indian trans-Himalaya: conflict perceptions and conservation prospects. Environ Conserv 24:338-343

Mishra C, Allen P, McCarthy T, Madhusudan M, Bayarjargal A, Prins HH (2003) The role of incentive programs in conserving the snow leopard. Conserv Biol 17:1512-1520

Moa PF, Herfindal I, Linnell JD, Overskaug K, Kvam T, Andersen R (2006) Does the spatiotemporal distribution of livestock influence forage patch selection in Eurasian lynx Lynx lynx? Wildl Biol 12:63-70

Mponzi BP, Lepczyk CA, Kissui BM (2014) Characteristics and distribution of live-stock losses caused by wild carnivores in Maasai Steppe of northern Tanzania. Hum Wildl Interact 8:218

Naughton-Treves L, Holland MB, Brandon K (2005) The role of protected areas in conserving biodiversity and sustaining local livelihoods. Annu Rev Environ Resour 30:219-252 
NCC-Group (2012) Five Year Strategic Plan for the Maleboch Nature Reserve, Limpopo, South Africa

Ngoprasert D, Lynam AJ, Gale GA (2007) Human disturbance affects habitat use and behaviour of Asiatic leopard Panthera pardus in Kaeng Krachan National Park, Thailand. Oryx 41:343

Norton P, Lawson A, Henley S, Avery G (1986) Prey of leopards in four mountainous areas of the southwestern Cape Province. South Afr J Wildl Res 16:47-52

Ogada MO, Woodroffe R, Oguge NO, Frank LG (2003) Limiting depredation by African carnivores: the role of livestock husbandry. Conserv Biol 17:1521-1530

Packer C, Brink H, Kissui B, Maliti H, Kushnir H, Caro T (2011) Effects of trophy hunting on lion and leopard populations in Tanzania. Conserv Biol 25:142-153

Palmeira FB, Crawshaw PG Jr, Haddad CM, Ferraz KMP, Verdade LM (2008) Cattle depredation by puma (Puma concolor) and jaguar (Panthera onca) in central-western Brazil. Biol Conserv 141:118-125

Paterson AR (2009) Legal framework for protected areas: South Africa. IUCN, Gland

Pauw K (2005) A profile of the Limpopo Province: demographics, poverty, inequality, and unemployment. PROVIDE Project

Phillips SJ, Dudík M (2008) Modeling of species distributions with Maxent: new extensions and a comprehensive evaluation. Ecography 31:161-175

Phillips SJ, Dudík M, Schapire RE (2004) A maximum entropy approach to species distribution modeling. In: Proceedings of the twenty-first international conference on machine learning. ACM, New York, p 83

Phillips SJ, Anderson RP, Schapire RE (2006) Maximum entropy modeling of species geographic distributions. Ecol Model 190:231-259

QSR International (2009) Nvivo qualitative data analysis software. Version 9.0. QSR

Ramphele N (1991) Restoring the land: environment and change in post-apartheid South Africa. Panos, London

Ray JC, Hunter L, Zigouris J (2005) Setting conservation and research priorities for larger African carnivores, vol 24. Wildlife Conservation Society, New York

Republic of South Africa (2013) What is LandCare?

Sangay T, Vernes K (2008) Human-wildlife conflict in the Kingdom of Bhutan: patterns of livestock predation by large mammalian carnivores. Biol Conserv 141:1272-1282

Schiess-Meier M, Ramsauer S, Gabanapelo T, König B (2007) Livestock predation-insights from problem animal control registers in Botswana. J Wildl Manag 71:1267-1274

Simcharoen S, Barlow AC, Simcharoen A, Smith JL (2008) Home range size and daytime habitat selection of leopards in Huai Kha Khaeng Wildlife Sanctuary, Thailand. Biol Conserv 141:2242-2250

Soto-Shoender JR, Giuliano WM (2011) Predation on livestock by large carnivores in the tropical lowlands of Guatemala. Oryx 45:561-568

Steinmetz R, Seuaturien N, Chutipong W (2013) Tigers, leopards, and dholes in a half-empty forest: assessing species interactions in a guild of threatened carnivores. Biol Conserv 163:68-78. doi:10. 1016/j.biocon.2012.12.016

Stephens D, Krebs J (1986) Foraging theory, vol 1. Princeton University Press, Princeton

Strang V (2010) Mapping histories: cultural landscapes and walkabout methods. In: Environmental social sciences: methods and research design. Cambridge University Press, Cambridge, pp 132-156

Swanepoel LH (2008) Ecology and conservation of leopards, Panthera pardus, on selected game ranches in the Waterberg region, Limpopo, South Africa. University of Pretoria, Pretoria

Swanepoel L, Lindsey P, Somers M, van Hoven W, Dalerum F (2012) Extent and fragmentation of suitable leopard habitat in South Africa. Anim Conserv 16:41-50

Teichman KJ, Cristescu B, Nielsen SE (2013) Does sex matter? Temporal and spatial patterns of cougarhuman conflict in British Columbia. PLoS ONE 8:e74663

Thorn M, Green M, Dalerum F, Bateman PW, Scott DM (2012) What drives human-carnivore conflict in the North West Province of South Africa? Biol Conserv 150:23-32

Thorn M, Green M, Scott D, Marnewick K (2013) Characteristics and determinants of human-carnivore conflict in South African Farmland. Biodivers Conserv 22:1715-1730

Tibane E, Vermeulen A (2014) South Africa Yearbook 2013/2014. South Africa Yearbook

Treves A, Karanth KU (2003) Human carnivore conflict and perspectives on carnivore management worldwide. Conserv Biol 17:1491-1499

Treves A, Wallace R, White S (2009) Participatory planning of interventions to mitigate human-wildlife conflicts. Conserv Biol 23:1577-1587

Wang SW, Macdonald DW (2009) The use of camera traps for estimating tiger and leopard populations in the high altitude mountains of Bhutan. Biol Conserv 142:606-613 
Woodroffe R, Frank LG, Lindsey PA, ole Ranah SMK, Romanach S (2007) Livestock husbandry as a tool for carnivore conservation in Africa's community rangelands: a case-control study. Vertebr Conserv Biodivers 5:419-434

Zarco-González MM, Monroy-Vilchis O, Rodríguez-Soto C, Urios V (2012) Spatial factors and management associated with livestock predations by Puma concolor in central Mexico. Hum Ecol 40:631-638 